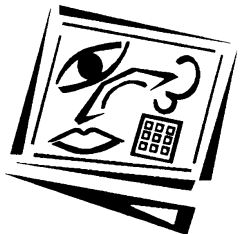

\title{
Strategic development of information technology services in a provincial higher education institute
}

Prachit Intaganok

Surindra Rajabhat University

Peter Waterworth

Deakin University

Siwaporn Srisamai

Surindra Rajabhat University

This paper describes a research project on the introduction of information technology (IT) services to a higher education institution in north eastern Thailand. The project considered the literature on the processes involved in the introduction of IT services to educational institutions in various parts of the world and attempted to understand the issues that institutions had to deal with in introducing and productively using IT services in teaching, scholarship and administration. It then analyses the nature of the process at the case study institution, through a range of quantitative and qualitative measures designed to draw data from staff, students and senior institutional managers. A number of similarities and differences were identified between what was found in the literature and what had occurred at the case study institution and analysis of them led to the development of a model to attempt to explain the attitudinal and practical stages through which an institution goes in adopting a technical innovation. The impact of cultural and contextual factors upon the acceptance of an innovation is stressed.

\section{Introduction}

The demand for economic progress in developing countries is often accompanied by a powerful (sometimes uncritical) appetite for technology. There is a need, not just for knowledge of what technological wizardry is available, but also of an understanding of the appropriateness and desirability of various kinds of equipment and applications. Higher education institutions should be strategically placed to provide such services to the community, particularly to the education community. They have large numbers of technologically hungry young people within them and are expected to have a transformative function within the society. Yet 
in many ways they are not fitted to respond adequately to the technological revolution. Their resources are severely limited and their expertise is incomplete. It seems that the speed of change and the overwhelming availability of technological options can, at best, confuse and, at worst, alienate or disempower many staff within them. The capacity of educational institutions to respond to the technological revolution is not straight forward. They must handle issues and tensions of various kinds, including

- the need to preserve local and national cultural formations

- the need to critically examine the technological products of powerful non-local cultures

- the need to revise means of social interaction and review traditional social structures

- the need to manage the fear of change

- the need to inspire confidence in the new and different.

This paper describes the way a Rajabhat Institute in north eastern Thailand is attempting to meet the challenges of technological change in both administrative and pedagogical functions. Rajabhat Universities form a significant tier of higher education in Thailand and were developed from the former teachers colleges. They now teach a range of courses and some (including Rajabhat University Surindra) were recently designated with university status. There are 41 Rajabhat Institutes in Thailand, one in each alternate province. Thai education blends together the values and systems of local and foreign cultures. It strongly reinforces Thai identity with all its refinement and sophistication and attempts to reconstruct traditional Buddhist sensibilities in its ethnically diverse population. Yet it embraces an awareness of the need for modernisation and it struggles to provide the best technological and economic skills the West can provide. Even though this paper reports upon research carried out in one institution, the issues with which it deals are commonly faced by many other similar institutions and the analysis and discussion of issues may be applied to other settings. We focused our investigation on the notion of computer usage and we considered that a critical understanding of information technology (IT) was largely dependent upon a level of familiarity with what was possible. Moreover, we wanted to ensure that our research findings would have some direct benefit to the institution in which the research was carried out in its assessment of its own technological capabilities and needs.

Our research question therefore, was 'what strategy may be used to increase educational computer usage in a provincial higher education institute in Thailand?' Our understanding of the notion of usage included not only the amount of usage, but also the quality and type of computer usage. We were interested to find out the factors affecting greater or lesser 
usage by staff, administrators and students, the nature of usage for educational purposes, and the application of information technology to administrative work within the institute. We were also interested in the links between each of these functions within the institute, and the opportunities to link local information with information from outside sources, both nationally and internationally. It was therefore important that research data be sought at a number of levels and from a variety of sources within the institute. Again, we saw it as important that questions of policy and direction be raised so that present and future strategies could be evaluated.

\section{Thai higher education and technology}

Recognising the importance of their leadership role in information technology, higher education institutions in Thailand have been vigorously developing information technology services in their institutions in instruction, administration and management, to perform a range of functions including

- staff and student access to the Internet

- instruction aided by data projection and computer assisted instruction (CAI)

- virtual libraries

- student enrolment and reporting of grades

- communication to staff, students and the general public through networking

Not all these functions have been achieved in all institutions and Rajabhat Institutes have been less capable of providing them. But along with other changes in education policy (such as the increase in autonomy for many higher education institutions) which are demanding the attention of university and Rajabhat councils, the IT Development Act (Charmonman \& Chorpothong, 2002) seeks to

- provide an IT infrastructure to serve all districts in the country

- develop an education network

- encourage and enable connection to the Internet in all educational institutions

- require the use of only legally produced software

- stimulate competition in the industry to reduce product costs, increase product quality and make servicing more accessible.

The Thai government has been actively developing an increasing capability in IT through education as demonstrated in its 1997 Constitution and 2002 Amended National Education Act. The rhetoric has been matched with 
specific funding of higher education institutions in training, technology infrastructure and software development (Whattananarong, 2004).

\section{Issues in the development of integrated IT systems}

The research literature on the introduction of integrated IT systems into Western higher education institutions since the late eighties and early nineties is replete with instances of the tensions and conflicts that accompany their introduction. While these effects may not necessarily be mirrored in equivalent developments in Thai institutions (since the technological sophistication of systems is far greater now), they may illustrate the kinds of issues to be faced. The Thai research on the same issues is beginning to appear in the Thai and English language literature. Our focus was upon what factors affected the initial development of IT services in educational institutions.

When IT services are integrated into the functions of an institution, the first kind of pressure experienced appears to be upon staff in their role performance, in the perception they have of the adequacy of their knowledge and skill base, and in their status relationships (Collis \& van der Wende, 2002; Bain, 2004). Institutions experience a high demand for increased training and support for staff and students (Oates, 2001) and pressure upon budgets to provide training and appropriate infrastructure to support the new innovation (Poole, 1997). Training needs to be tailored to the specific needs of the learners (McNaught, Phillips, Rossiter \& Winn, 2000), and even then is not effective unless it meets the personal and organisational expectations (Pressman, 1997; Oates, 2001; Kenny, 2004). Increasing the skill levels of some creates a powerful division between IT literate and semi- or non-literate staff and students, and tends to alienate or disempower the less competent (Murphy, 1987; Green \& Bigum, 1992). The less technically competent may often include senior institute personnel whose lack of skill makes it difficult for them to contribute effectively to decision making processes in regard to IT policy and development (Yetton, 1997; Laurillard \& Margetson, 1997; Poole, 1997; Prpic \& Kanjanapanyakom, 2004). In Thailand in particular, the presence of more IT literate junior staff in decision making forums may unsettle the position and authority of their less competent superiors (Waterworth \& Tesaputa, 1999; Prpic \& Kanjanapanyakom, 2004; Gray \& Sanzogni, 2004). As staff cope with new IT systems, roles change and new roles are created as others disappear, often destabilising existing hierarchical staff structures (Murphy, 1987; Poole, 1997).

As IT services develop, institutions face further challenges in the way they structure or restructure the organisation, manage staff and promote the academic purposes of the institution. IT facilities may be introduced in a 
haphazard and uncoordinated way across an institution and the need to amalgamate services to make more judicious and economic use of them eventually becomes apparent (Neff, 1985). The functional links between previously discrete units in the institution are merged through a network and in themselves, create further inter-divisional tensions (Bailey, Bromage \& Creer, 2000; Kennedy, Webster, Benson, James \& Bailey, 2002; Katz \& Salaway, 2004). The network combines the authority structure, administrative organisation, research infrastructure and teaching systems (Gibson, 1995; Kahn, 1997; Relan \& Gillani, 1997; Freeman, 1997; Venables, 1998; Bennett, Priest \& Macpherson, 1999). The web becomes available for educationally sound integration into the teaching system (Intaganok, 2001; Waterworth, Segrave \& Warren, 2001; Suangpang \& Petocz, 2004; Evans \& Gunter, 2004).

\section{Method}

Our study of the literature, and our combined experience of working within a range of institutions in the West and South East Asia, indicated that these effects might be observed in Thai institutions as they worked through the same processes in the integration of IT services in their institutions. We were interested in testing such a proposition in this project.

We wanted to address our research question by drawing data from a number of sources and of a variety of types. We felt that computer usage by staff and students should be measured in quantitative as well as qualitative ways to provide us with a complete picture of the extent and quality of usage. We decided to survey students from each of the five faculties from undergraduate and graduate classes with studies in both computer intensive and non-computer intensive courses. We selected staff from each of the faculties who were knowledgeable about computer use within their faculties and invited them to join a focus group discussion. We interviewed management personnel on their opinions of the qualities of the current provision of IT services and their vision for future development of services.

\section{IT services at the Institute}

Surin is five hours by road from Bangkok in the economically poor region of southern Isaan. The Surin Province borders Cambodia and more than 60 per cent of the local population is ethnically Khmer, being Thai second language speakers, and often experiencing disadvantaged schooling. The Institute is a major organisation in the province and entry to it is highly prized by local students. It has a student population of 7,334 and staff (including both academic and administrative staff) of 335. It offers courses in education and related disciplines at the central campus in Surin and in 
outlying places in surrounding provinces. None of its courses are offered in off campus or online mode.

The Computer Centre at the institute is in its infancy having been established in 1997 (along with computer centres in other Rajabhat Institutes). It has a digital alpha server, digital router and 40 computers under its direct management and a further 300 or so computers in various sections of the campus linked to its server. The Centre consists of an administrative office, a laboratory and a lecture room. There are further computer classrooms throughout the faculties which serve particular faculty functions and these are not managed by the Computer Centre. A local area network (LAN) was established in 1999 with links from the Computer Centre to ten other areas. All networked computers provide unrestricted and unrecorded access to the Internet, although off site connection to the network is not possible at this stage. As many as 25.6 percent of computers are not linked to the LAN.

The Computer Centre directly employs four staff, one of whom (the Computer Centre Manager) has a full time teaching load. The Centre is supported by a network of interested and knowledgeable academic staff who offer their time voluntarily to the Computer Centre. Moreover, some of these staff form the Computer Centre Committee, an advisory committee to the Computer Centre Manager.

\section{Results}

\section{Student questionnaire}

The questionnaire to students was distributed in class to all students in the sample in the same teaching week. The questionnaire was composed in the Thai language and data entry (using SPSS) was also done in Thai. There were 187 respondents (a 100 per cent response rate) of whom 56.7 per cent were male and 43.3 female. The strong male representation was partly due to the fact that one faculty, Industrial Technology, has only male students. Males were therefore slightly over represented in the sample. The age distribution of the sample was fairly typical of the population from which the sample was drawn with 42.5 per cent of the sample being 20 or under and 41.9 per cent being between 21 and 25 . The sample was drawn from 2year Certificate and Diploma courses (34.4 per cent), 4-year undergraduate Degree courses (48.4 per cent) and 2-year graduate Masters courses (17.2) which again was fairly typical of the population from which the sample was drawn. The diploma and graduate level students were slightly over represented in the sample but this was thought to be insignificant.

Table 1 shows the Faculties from which respondents came. Each of the five faculties was represented in the sample with the largest group (34.1 per 
cent) coming from the Faculty of Industrial Technology. No faculty strongly dominated the sample. The sample from the Faculties of Education and Humanities and Social Sciences contained only graduate students. They were the only faculties with graduate programs. Overall, graduate students are not strongly represented in the institute and this was reflected in the sample.

Table 1: Faculty of respondent $(\mathrm{N}=186)$

\begin{tabular}{|c|c|c|}
\hline Faculty & Number & Percent \\
\hline Education & $14^{*}$ & 7.6 \\
\hline Humanities and Social Sciences & $19^{*}$ & 10.3 \\
\hline Science and Technology & 38 & 20.5 \\
\hline Management Sciences & 51 & 27.6 \\
\hline Industrial Technology & 63 & 34.1 \\
\hline
\end{tabular}

\section{Student use of computers}

Students used the computers at the institute (outside normal classroom activities) at various intervals of time as shown in Table 2.

Table 2: Frequency of computer use (excluding regular classes) $(\mathrm{N}=184)$

\begin{tabular}{|l|c|c|}
\hline \multicolumn{1}{|c|}{ Frequency of use } & Number & Percent \\
\hline Everyday & 10 & 5.4 \\
\hline Once every 2-3 days & 30 & 16.3 \\
\hline Once a week & 22 & 12.0 \\
\hline Once every 2-3 weeks & 18 & 9.8 \\
\hline Once a month & 7 & 3.8 \\
\hline Rarely use & 54 & 29.3 \\
\hline Never use & 43 & 23.4 \\
\hline
\end{tabular}

A surprisingly large number of students 'rarely' or 'never' used computers at the institute - as many as 52.7 per cent. The group that never used the computers had their responses eliminated from the analysis of questions on the quality of computer use since their responses may have skewed the nature of knowledgeable responses, that is, from Tables 3 and 4 . Computer use was not extensive amongst other students as well, with only 5.4 per cent using computers for any purposes every day.

Measures of significance showed that there was no relationship between the age of students and the regularity with which they used computers. Use of computers was so spasmodic that no patterns across age groups emerged in this study. 
Table 3: Time span of computer use per time (excluding regular classes) $(\mathrm{N}=131)$

\begin{tabular}{|l|c|c|}
\hline \multicolumn{1}{|c|}{ Time span of use } & Number & Percent \\
\hline Less than 10 minutes & 21 & 16.0 \\
\hline 10-30 minutes & 36 & 27.5 \\
\hline 31 minutes to 1 hour & 45 & 34.4 \\
\hline Above one hour & 29 & 22.1 \\
\hline
\end{tabular}

Table 3 shows the amount of time students spent when using computers at the Institute. Most students used the computers for between 30 minutes and one hour (34.4 per cent). The vast majority of use, at 77.9 per cent, was for less than one hour indicating that there was a constant turnover of student users at the computers. Student use of the computers was therefore economical and this allowed more users to benefit from the facilities provided.

Our project focused attention on the educational uses of IT facilities compared to recreational use. Table 4 shows that the majority of use of computers in students' free time was not associated with educational tasks.

Table 4: Purposes of computer use $(\mathrm{N}=131)$

\begin{tabular}{|l|c|c|c|c|}
\hline \multirow{2}{*}{\multicolumn{1}{|c|}{ Purpose of use }} & \multicolumn{2}{c|}{$\begin{array}{c}\text { Very often and } \\
\text { Sometimes }\end{array}$} & \multicolumn{2}{c|}{ Never } \\
\cline { 2 - 5 } & $\mathrm{N}$ & Percent & $\mathrm{N}$ & Percent \\
\hline Search information from Internet & 100 & 76.3 & 31 & 23.7 \\
\hline Check information from RIS web page & 99 & 75.6 & 32 & 24.4 \\
\hline Typing report & 96 & 73.3 & 35 & 26.7 \\
\hline Working on class assignment & 88 & 67.2 & 43 & 32.8 \\
\hline Send or receive emails from friends & 83 & 63.4 & 48 & 36.6 \\
\hline Chat room & 76 & 58.0 & 55 & 42.0 \\
\hline Play games & 70 & 53.4 & 61 & 46.6 \\
\hline Email to lecturers & 38 & 29.0 & 93 & 71.0 \\
\hline ICQ & 31 & 23.6 & 100 & 76.3 \\
\hline Online conference or meeting & 4 & 3.1 & 127 & 96.9 \\
\hline
\end{tabular}

For the purposes of this analysis, the following tasks were considered educational (with the percentage of students who performed these functions 'sometimes' or 'very often' shown in brackets after each factor).

- searching for information on the Internet (76.3\%) a task not necessarily associated with educational purposes

- consulting the Institute's web page $(75.6 \%)$

- typing reports $(73.3 \%)$

- working on class assignments $(67.2 \%)$ 
- $\quad$ sending emails to lecturers $(29.0 \%)$

- conferencing (3.1\%; surprisingly, a facility not available within the institute when the survey was done.

The most common uses of the system were for routine secretarial or consulting tasks - not those associated with academic communication or discourse except for the search function. The questionnaire did not distinguish between searching for academic or recreational purposes but we suspect that most of the searching may have been related to the latter. There were no measures of significance between types of students on any one of these factors (using Spearman's Rank Order correlation with a measure of significance at the 0.05 level). In particular, regularity of use was not associated with any particular type of educational use of facilities. The way IT was used in learning in a Thai higher educational institution was not addressed in this research.

Recreational use of the IT facilities was high with larger numbers of students commonly using the facilities for these reasons. The percentage making recreational use of facilities 'sometimes' or 'very often' for each item was

- sending or receiving email from friends $(63.4 \%)$

- chat room $(58.0 \%)$

- playing games $(53.4 \%)$

- ICQ $(23.6 \%)$

The use of these functions was of course, proportionate to students' knowledge and skill in using these functions, not simply in their choice of use of the function. ICQ usage was probably less well known by students and the usage of it was therefore lower. The use of communication through emailing was quite high and indicates the potential to use this function educationally. Since Internet access from home was most uncommon for students, it was not surprising that emailing functions were well used at the institute.

Table 5: Student opinions on areas for future development

\begin{tabular}{|l|c|c|c|c|}
\hline \multicolumn{1}{|c|}{ Desired improvement } & $\mathrm{N}$ & $\begin{array}{c}\text { 'Strongly } \\
\text { agree' and } \\
\text { 'Agree' }\end{array}$ & $\begin{array}{c}\text { 'Strongly } \\
\text { agree' only }\end{array}$ & $\begin{array}{c}\text { 'Disagree' or } \\
\text { 'Strongly } \\
\text { disagree' }\end{array}$ \\
\hline More computer laboratories & 178 & 84.0 & 71.8 & 5.5 \\
\hline $\begin{array}{l}\text { Extend opening hours of labs beyond } \\
4.20 \text { pm }\end{array}$ & 177 & 42.8 & 18.3 & 28.3 \\
\hline More instruction using computers & 117 & 39.4 & 10.6 & 19.4 \\
\hline Offsite access & 176 & 39.4 & 18.9 & 26.1 \\
\hline More training for students & 176 & 38.5 & 18.4 & 27.4 \\
\hline $\begin{array}{l}\text { More lecturers to use computers in } \\
\text { their teaching }\end{array}$ & 177 & 24.4 & 12.8 & 50.0 \\
\hline
\end{tabular}


Students indicated their preferences for increased IT facilities and services and their responses are shown in Table 5. The overwhelming perceived need was for more computer laboratories to be provided. The overbooking of facilities and crowding at various times during the day was obviously found to be annoying for students. As student usage increases in the next few years, the current facilities will be further overtaxed and this request for more facilities will need to be met. Undergraduate students were significantly more likely to want greater access to laboratories than graduate students. This was an opinion expressed on the basis of experienced need, since undergraduate students were more likely to experience the large demand for facilities than the graduate (in service) students. The other possible developments to the IT services were less strongly affirmed, but still remained significant. The next most felt need was for extended opening hours for laboratories. At present, facilities are not open after $4.20 \mathrm{pm}$ or on weekends, despite the fact that all graduate classes are held on weekends. Graduate students were significantly more likely to want their lecturers to use computers in their teaching presentations.

\section{Interviews with key institute personnel}

We interviewed the three most senior and influential members of the management team of the Institute who held direct responsibility for the operation of IT services. Interviews were conducted in a combination of English and Thai with the three researchers present at each interview. Two of the senior personnel were fluent in English and one was not and questions were asked first in English and then Thai. Responses were recorded in writing in both English and Thai. We were interested in the perceptions these key individuals had of the strategies, policies and procedures used in IT services. We focused therefore on the issues which the Institute was tackling in providing services and in seeking to improve those services. The opinions of these staff were regarded as significant in shaping policy as well as approving strategies for development of IT services.

A number of issues appeared to emerge in the interviews as the major issues with which the Institute was grappling

\section{Maximising the system}

While tremendous progress had been made in building up IT services, the system was not used by staff and students to its fullest extent.

Our system is running efficiently and we are able to integrate new

technology and software into the system quite well. Computer Centre Manager 
We can cope with IT changes at RIS and we can learn more about making more extensive use of the system. Institute Manager A

The senior management were happy with the progress that had been made in the introduction of the system. Yet the system was not being used to its fullest extent. While there was scope for better use of the system, certain impediments to its use existed, including the separate development of departmental facilities and the lack of cooperation between departments in the use of these facilities.

Each department has its own computer network, developed separately without reference to a main plan. Computer Centre Manager

The Computer Centre Manager saw this as a serious problem that limited resource access rather than increasing it. Separate development may have served specialised departmental needs, but the lack of an overall developmental strategy encouraged unwise spending of limited funding, duplication of systems and facilities and prevention of purchase of basic or fundamental hardware or software. This problem was particularly evident in the limited cooperation between the Computer Centre and the Library. Because their functions were conceived separately, separate development of facilities has been allowed to occur. Cooperation was limited to the provision, by the Computer Centre, of networked computers to the Library, while the strategic development of storage, collection and distribution facilities between the two divisions did not occur. In addition, while faculties could operate networks independently of each other, an overall policy that the network be owned and managed centrally appeared not to have effect.

\section{Maximising educational and administrative functions}

Staff and students were unlikely to make maximal use of the IT services offered by the institute because of a number of factors. Only a small percentage of academic staff used computers in their academic work or included use of computers in their courses. This was because of unfamiliarity with the system, lack of confidence in the system (hardware) and a sense of lack of necessity to use the IT services.

Most staff have a computer on their desks but they only use them for word processing - not even for emailing. Institute Manager A

Staff expertise was also said to be limited so that the capacity to use elearning was thought to be confined to the use of commercially produced programs.

As a Rajabhat Institute, we have no power to be the producers of CD Roms and e-learning, only users. Institute Manager $A$ 
Despite this opinion, staff and students were producing CDs and elearning programs in certain fields. Students were also seen by the senior managers to be limited in their competence to use computers.

\begin{abstract}
Students have poorer achievement levels to enter Rajabhat Institutes than to universities and their self motivation in using computers is therefore lower. Many of our students come from very poor families. Less than 10 per cent have a computer at home and less than 5 per cent would be connected to the Internet at home. Yet they all have a need to make use of IT while at the institute. Institute Manager A
\end{abstract}

Our students, even at postgraduate level have a poor grasp of English and are therefore limited in their use of English language based materials and resources available through the web. Institute Manager B

While there were, by then, several Thai language search engines, the number of scholarly materials available through them was far less extensive than the English language based materials.

Opinions on the administrative functions available through the system varied, with one saying that many functions were now available and another that systems were yet to be installed. This betrayed a degree of uncertainty among senior staff about existing, and soon to be available, administrative functions.

\title{
3. Making best use of limited financial resources
}

Government funding was available for special purchases of hardware, software and services and for recurrent spending, but it was severely limited considering other institutional demands. Internet access was provided through these funds with no download limits, promoting haphazard and undirected use of the service.

We are a small college with poor students and lower fees than other Rajabhat Institutes. We don't receive much in fees or from government sources. Institute Manager A

A proportion of student fees go to specified divisions within the institute but under Rajabhat Council rules, none can be allocated to IT services. Computer Centre Manager

Limited budgets caused a number of problems in the provision of IT services. Apart from limiting purchases and maintenance, they prevented the acquisition of sufficient protection and security of services, created an acceptance of pirated or inferior software and limited the availability of training services for students and staff. The Institute then had a policy to regularise the use of legal software and install protection on the LAN. The 
Institute had accepted responsibility for developing an awareness of local Indochinese cultures and languages - some of which were becoming extinct - and it saw its developing expertise in local culture as something to be recorded, studied, preserved and communicated. It was the President's wish that IT services be used in this process of preservation and dissemination.

\section{Standardising the provision of IT services across the Institute}

The Institute had not developed clearly articulated or widely agreed strategies or policies for the development of IT services. Decisions about the direction of policy development had been made progressively in response to funding strictures, Rajabhat Council decisions, faculty needs, and the influence of key decision makers.

Most policy decisions are budget driven. Institute Manager A

We do not have time to discuss policy with high ranking staff and there probably is not sufficient communication between the Computer Centre and Senior Management. I have a 'mission' or a 'plan' of what I want to achieve in the Computer Centre and we have a Computer Centre Committee to discuss the possibilities of the future. Computer Centre Manager

As IT services expanded, there might have been an increasing need for the staging of growth targets and training targets to eliminate wastage and to focus development.

\section{Staff focus group findings}

Nominated faculty representatives attended a focus group, having prior notice of the group discussion topics, namely, the use of IT in instruction, problems and concerns of academic staff on the use of IT, and future development of IT services at the institute. Focus group research procedures were explained to the group at the beginning of the session and the notion of participant agreement on key points was stressed. Invitations to the participants to join the focus group and notification of the topic questions were in the Thai language. The focus discussion was conducted in English with Thai interpretation. Focus group agreements were recorded on a whiteboard in Thai and English.

The focus group provided more comprehensive insights into the use of IT services for academic staff and students and described the better and less helpful aspects of IT services at present. They were able to articulate the factors which assisted the introduction and use of IT services and those factors working against effective use. 
Factors which assisted or promoted the better use of IT services by academic staff were:

- having better IT competence

- teaching or working in the IT field

- selecting easier to use functions such as word processing and PowerPoint

- possessing (or working towards) an English language based higher degree

- being familiar with the range of functions of IT services and the appropriateness of certain functions for day to day work.

PowerPoint presentations are generally used in some of our teaching. Focus group participant $C$

Factors which assisted or promoted better use of IT services by students were:

- taking a course in the IT field

- being able to read in English

- appreciating the suitability of particular IT functions to their study area.

Factors which blocked or discouraged academic staff from using IT services more efficiently were:

- the lack of an institutional expectation that IT services be used in day-today work of staff

- an absence of a large core of staff who commonly use IT services in their day to day work - especially in communication and data storage and manipulation

- a lack of appreciation of the capabilities and value of IT services to academic functions

- inadequacies of the system such as slowness of downloads, extensive downtime and insufficient number of computers for staff

- the high work load of academic staff (some working a seven day week)

Factors which blocked or discouraged students from using the IT services more efficiently were:

- a lack of sufficient motivation to use IT services

- the lack of pressure or influence from lecturers for students to make greater use of facilities

- heavy timetables for students and overbooking of IT labs at times when students had time to work in the labs

- restricted hours of opening for IT labs.

Academic staff were hampered in their use of IT by

- their own lack of skill in using computers 
- the lack of adequate professional development for staff in using IT

- the lack of sufficient incentive for staff to make themselves IT literate

- the lack of English language to enable them to use web based communication and perform searches for information.

We strongly feel that language (English) is a major barrier for us in using IT. Focus group participant $D$

A small minority of staff was highly and increasingly well skilled in using IT and they were able to use digital technology in their teaching and encourage students to use computers in assessed work.

Most of us have our own email addresses but we don't use them. There is no need to communicate with others and no one sends us messages. Focus group participant $E$

Academic scholarly work was again rarely enhanced by IT for most staff. Where it was used in scholarly activities, it was limited to mainly searching and did not include communication.

Internet is used mainly to obtain learning resources but not as a communication tool. Focus group participant $F$

The staff suggested that there be a computer on each academic staff member's desk, or, short of that, the supply of Internet capable facilities to each faculty. The Internet connection was also highly unstable and slow. It was often unavailable for periods of a few days on a regular basis because of network or provider problems. Even though most staff had Internet addresses, inter-staff communication was severely limited and was undertaken only by the ten to twelve highly committed staff out of more than 300 academic staff.

Staff were able to use the LAN for a number of administrative tasks such as obtaining student lists, timetable and resource allocation, human resources information, lists of texts and course summaries. Staff stated that student access was generally restricted because of crowded and overbooked laboratory facilities. Student use was confined to certain student subgroups and training and motivation for all students should be a high priority.

\section{Discussion}

\section{Cultural and contextual factors}

Any new technological innovation is certain to impact different populations in different ways, if only because of the contextual differences within which the innovation has been introduced. The local institutional 
and cultural environments in this case study had a profound impact upon the way IT services were introduced to this institution. The size of the institution, its location in an economically and educationally disadvantaged area in north eastern Thailand and consequently, its limited financial resources were major factors affecting the introduction of IT services. Although the institution had a desire to capture and communicate the cultural uniqueness of the Institute's geographical location through use of IT services, the limited budget within which the institution worked prevented the adequate development of IT services to meet such a desirable aim. IT services were barely able to meet teaching and administrative needs. Extensive student poverty made it impossible for students to compensate for the Institute's sparse resources by use of computers at home (let alone those connected to the Internet). The lack of English competence amongst staff and students and the inadequate provision of Thai language educational resources on the Internet rendered Internet connection a less desirable and infrequently accessed service.

\section{Limited IT literacy}

This project clearly demonstrated the striking differences between people (both staff and students) in their IT literacy and the impact of those differences upon attitudes towards the value and use of IT services. There were significant factors involved in people becoming more IT literate. The more competent users were generally working in the IT area or in a field where IT had to be used more frequently, had a better understanding of English (from either learning it or studying in it), or had a more comprehensive understanding of the range of IT services available and of how IT functions related to their academic or administrative work.

\section{Development of strategies and policies in IT management and use}

Strategies for the introduction and use of standardised IT services in the Institute were now gradually having effect in contrast to the haphazard development of non-integrated systems of the last few years. There was still resistance to the notion of an integrated system and to centralised control and management of facilities and resources. Policies and protocols were also being slowly introduced to provide a consistent, fair and efficient service to staff and students. At the moment, policy on the development of IT services was still piecemeal and subject to change at short notice. There was still the opportunity for the independent or maverick development of IT resources and the direction of development was still subject to one off budget decisions. 


\section{Progress in the introduction of IT services}

Our earlier review of the literature reported on the kinds of issues which arose when institutions began to develop their IT services. We noted a number of consequences for the teaching and learning environment and the management and administrative structures of institutions. Two of the issues raised in the literature were clearly demonstrated in our case study as discussed above, namely, the existence of an ever widening gap between IT literate and illiterate people at the institution and the haphazard and ununified development of IT facilities. Other issues identified in the literature were beginning to become apparent at our case study institution.

These were an increasing need for training in IT, increased functions and roles for the Computer Centre and Library, and revision of role descriptions and statuses of IT personnel. While we found a great need for IT training, we did not detect a large demand for training across the institution. Some realised their need for training but others expressed a simple desire to know more without quite knowing what they needed. However, the other issues we identified in our literature search as being significant markers of institutions emerging from the predigital age, were not apparent in our case study. These issues related to the use of the network to integrate the functions of teaching, learning, research and administration, the merging of teaching and learning functions, increasing need to use the web in teaching and administration, introduction of new and revised staff and student protocols and increased inter-institutional cooperation and competition.

These analyses led us to consider whether there might be some kind of hierarchy of experiences in an institution coming to terms with IT services and in understanding the new possibilities and capabilities of IT. We developed, therefore, a model (see Table 6) to attempt to explain the progression towards a digitally competent institution, hoping that such a model would be useful in explaining developmental issues in other places - not simply in our case study institution. We suggest that the first level of issues faced by institutions arise from the 'shock of the new'. As the technology becomes better known and begins to intrude into the operation of an organisation, certain instabilities begin to emerge. Some people become the new experts and others are by-passed. Some grasp the new technology with vigor while others deliberately ignore it. This leads to a sporadic or uneven development and use of the new technology and led us to call this stage the Idiosyncratic Stage.

The second level of issues arises from the formal acceptance of the innovation by the organisation and recognition of the need for the innovation. At this stage, the innovation is formally accepted as essential to 
the organisation and the destabilisation that the innovation brings is recognised. There is a formal endorsement of the innovation by the organisation and an attempt by it to have members retrained to use the technology more efficiently. At this stage, cynicism about the innovation is and remains quite prevalent, and uncertainty about the impact of the innovation upon authority structures within the institution is evident. We have labeled this level the Partial Stage, because even though the innovation has been adopted by the organisation, there is widespread skepticism about the effectiveness of the innovation and the cost benefits the innovation is said to bring to the organisation.

Table 6: Introducing IT services to an institution

\begin{tabular}{|c|c|c|c|c|}
\hline & Stage & Characteristics & \begin{tabular}{|c|} 
Level of \\
acceptance
\end{tabular} & Issues of adoption \\
\hline 1 & $\begin{array}{l}\text { Idiosyn- } \\
\text { cratic }\end{array}$ & $\begin{array}{l}\text { Uneven } \\
\text { acceptance of } \\
\text { innovation. The } \\
\text { IT literate } \\
\text { display an } \\
\text { evangelistic zeal } \\
\text { for the } \\
\text { innovation }\end{array}$ & Individual & $\begin{array}{l}\text { Institution supports the establishment } \\
\text { of non-integrated, unlinkable facilities } \\
\text { and software. } \\
\text { Need for central management of IT } \\
\text { services is recognised and Computer } \\
\text { Centre is established with limited } \\
\text { funding. } \\
\text { Local Area Network (LAN) with } \\
\text { limited functions is established } \\
\text { Non-IT literate people feel alienated } \\
\text { and may attempt to reduce the } \\
\text { innovation's acceptance. }\end{array}$ \\
\hline 2 & Partial & $\begin{array}{l}\text { Official } \\
\text { sanctioning of } \\
\text { the innovation } \\
\text { but widespread } \\
\text { mistrust of the } \\
\text { innovation and } \\
\text { active resistance } \\
\text { to the } \\
\text { innovation by } \\
\text { some }\end{array}$ & $\begin{array}{l}\text { Individual } \\
\text { and } \\
\text { institut- } \\
\text { ional }\end{array}$ & $\begin{array}{l}\text { Appropriateness of IT applications to } \\
\text { education and administration is } \\
\text { partially demonstrated. } \\
\text { Need for large scale training for staff is } \\
\text { recognised but IT literate are most } \\
\text { likely to attend. Training budget is } \\
\text { limited. } \\
\text { Manual roles in administration begin to } \\
\text { disappear. Managerial roles begin to } \\
\text { include production and use of } \\
\text { organisational data. } \\
\text { Roles of Computer Centre and Library } \\
\text { expand to include superior methods of } \\
\text { storage, manipulation and } \\
\text { dissemination of information, and to } \\
\text { provide better support for media } \\
\text { production and educational } \\
\text { development. } \\
\text { LAN expands to include better } \\
\text { communication functions and to } \\
\text { integrate teaching, research and } \\
\text { administration. }\end{array}$ \\
\hline
\end{tabular}




\begin{tabular}{|c|c|c|c|c|}
\hline 3 & $\begin{array}{l}\text { Institut- } \\
\text { ionalised }\end{array}$ & $\begin{array}{l}\text { Integration of } \\
\text { innovation into } \\
\text { formal and legal } \\
\text { processes of } \\
\text { institution }\end{array}$ & $\begin{array}{l}\text { Institut- } \\
\text { ional }\end{array}$ & $\begin{array}{l}\text { LAN is used for official notification of } \\
\text { matters to staff and students. } \\
\text { All staff and students are expected to } \\
\text { use the LAN in educational and } \\
\text { institutional communication. } \\
\text { All staff and students are provided } \\
\text { with LAN accounts and usage is } \\
\text { monitored. Download limits are } \\
\text { imposed to increase speed and } \\
\text { efficiency of LAN. } \\
\text { IT is commonly used in teaching in all } \\
\text { courses and all subjects } \\
\text { Web based learning is used in teaching } \\
\text { in all courses and all subjects. } \\
\text { Web based literature reviews are } \\
\text { commonly used in academic research } \\
\text { by staff and postgrad students. } \\
\text { The institution's web page becomes } \\
\text { interactive (or a portal is established) } \\
\text { with variable password protected } \\
\text { access and administrative functions are } \\
\text { performed through the web }\end{array}$ \\
\hline
\end{tabular}

The third level of issues arises out of the formalisation and legitimisation of the innovation within the normal day to day processes of the institution and the procedural and legal structures of the institution. At this stage, acceptance and competent use of the innovation is built into the normal functions of the institution, all members of the institution are expected to use them and the competent use of the technology is linked to successful performance of roles within the institution.

\section{Conclusion}

This case study is not simply the story of the way a technical innovation can intrude into an organisation and cause values, people and systems to change. Since the innovation we were studying concerned the fundamental perceptions we have about education, administration, media, scholarship, organisations and work, we were examining changes to lifestyles and personal identities in reporting this project. To a certain extent, this became a study on the impact of change upon human existence. It was important therefore, that we attempted to trace the way change impacted people in different ways and how an organisation attempted to control and manage that impact. Moreover, it was important to see this research as a way in which cultures attempt to protect themselves and to orchestrate change. Within those cultures, of course, the edifices of power relationships were to be challenged or shielded. The natural tensions within cultures would be revealed in a study of this kind as power or significance shifted from one 
individual to another, from one group to another and from one set of values to another. We emphasised the need for the creation of a particular kind of digital community within which ideas are shared, mentoring and learning take place, and interest and enthusiasm are generated. At the moment, this community exists in a very small way amongst a few committed staff at our case study institution, but we see its growth as essential to provide an environment of learning and mutual support.

Our most significant outcome, however, was to describe the introduction of IT services in terms of a staged process, firstly affecting particular adventurous individuals and eventually gaining overall acceptance and indeed legitimacy from the organisation and consequently, impacting all people within the organisation. We suggested that a three phase model best described the process of change, and that most institutions would find these stages reflected in their experience. Our case study institution was, according to our findings, moving between stages 1 and 2. Many questions relating to the educational use of IT in Thailand and the way staff and students in higher education institutions adapt to the use of IT could not be posed in this research project and might form the basis for future research.

\section{Acknowledgements}

The authors gratefully acknowledge research funding from the Rajabhat University Surindra in Surin to support the project described here.

\section{References}

Bailey, N., Bromage, A. \& Creer, A. (2000). My.university: Personalized portals in Perl. In J. Orwant (Ed), Proceedings of the Perl Conference 4.0, O'Reilly and Associates, Monterey, 51-59.

Bain, A. (2004). Secondary school reform and technology planning: Lessons learned from a ten year school reform initiative. Australasian Journal of Educational Technology, 20(2), 149-170. http: / / www.ascilite.org.au/ajet/ ajet20/bain.html

Bennett, S., Priest, A. \& Macpherson, C. (1999). Learning about online learning: An approach to staff development for university teachers. Australian Journal of Educational Technology, 15(3), 207-221.

http:/ / www.ascilite.org.au/ajet/ajet15/bennett.html

Charmonman, S. \& Chorpothong, S. (2002). Strategies for developing "autonomous" universities and colleges: Meeting the goals of the Ninth National Education Development Plan. Paper presented at a conference Strategies for developing 'autonomous' universities and colleges: Meeting the goals of the Ninth National Education Development Plan. Faculty of Education, Assumption University and College of Education, Washington State University at Assumption University, Bang Na. 
Collis, B. \& van der Wende, M. (Eds) (2002). Models of technology and change in higher education. Center for Higher Education Policy Studies, University of Twente, Enschede [viewed 31 Oct 2005] http: / / www.utwente.nl/ cheps/ documenten/ictrapport.pdf

Cooley, M. (1992). Human-centred education. In C. Bigum \& B. Green (Eds), Understanding the new information technologies in education. Centre for Studies in Information Technologies and Education, Deakin University, Geelong.

Corderoy, R. (Ed) (1998). Flexibility: The next wave? Proceedings of the 15th ASCILITE, University of Wollongong, Wollongong. [verified 31 Oct 2005] http: / / www.ascilite.org.au/conferences/ woolongong98/ascpapers98.html

Evans, B. P. \& Gunter, G. A. (2004). A catalyst for change: Influencing teacher technology proficiency. Journal of Educational Media and Library Sciences, 41(3), 325-336.

Freeman, M. A. (1997). Flexibility in access, interaction and assessment: The case for web-based teaching programs. Australian Journal of Educational Technology, 13(1), 23-39. http: / / www.ascilite.org.au/ajet/ ajet13/freeman.html

Gibson, J. (1997). Evaluation of a trial of Internet teaching in TAFE NSW. Proceedings AusWeb97. http:// ausweb.scu.edu.au/aw97/papers/gibson/paper.htm

Gray, H. \& Sanzogni, L. (2004). Technology leapfrogging in Thailand: Issues for the support of e-commerce infrastructure. Electronic Journal on Information Systems in Developing Countries, 16(3) 1-26. [viewed 31 Oct 2005] http:/ / www.is.cityu.edu.hk/ research/ejisdc/vol16/v16r3.pdf

Green, B. \& Bigum, C. (1992). Introduction. In C. Bigum \& B. Green (Eds), Understanding the new information technologies in education. Centre for Studies in Information Technologies and Education, Deakin University, Geelong.

Intaganok, P. (2001). A comparison of instruction through Internet with and without informing student surfing paths upon learning achievement of upper secondary school students with different learning styles' education. In Lertchalolarn, C. et al (Eds), Reforming teacher education for the new millennium: Searching for new dimensions. Proceedings of the International Conference, Chulalongkorn University in association with SEAMEO RIHED, Bangkok, July 2000.

Kahn, B. H. (1997). Web-based instruction (WBI): What is it and why is it? In B. H. Kahn, Web-based Instruction. Educational Technology Publications, Englewood Cliffs NJ.

Katz, R. N. \& Salaway, G. (2004). Information technology leadership in higher education: The condition of the community. Educause Center for Applied Research. [viewed 31 Oct 2005]. http: / / www.educause.edu/ers0401/

Kennedy, D. M., Webster, L., Benson, R., James, D. \& Bailey, N. (2002). My.monash: Supporting students and staff in teaching, learning and administration. Australian Journal of Educational Technology, 18(1), 24-39. http: / / www.ascilite.org.au/ajet/ajet18/kennedy.html 
Kenny, J. (2004). A study of educational technology project management in Australian universities. Australasian Journal of Educational Technology, 20(3), 388404. http: / / www.ascilite.org.au/ajet/ajet20/kenny.html

Laurillard, D. \& Margetson, D. (1997). Introducing a flexible learning methodology: Discussion paper Number 7. Griffith Institute for Higher Education, Griffith University, Brisbane. [for part availability, see http:/ / www.griffith.edu.au/centre/ gihe/teachinglearning/flexiblelearning/modules/whatismodule/Laurillard.PDF]

McMahon, M. (1997). Social constructivism and the World Wide Web - A paradigm for learning. In R. Kevill, R. Oliver \& R. Phillips (Eds), What works and why. Proceedings of ASCILITE 1997 Conference, 411-417. http:/ / www.ascilite.org.au/conferences/ perth97/ papers/Mcmahon/Mcmahon.html

McNaught, C., Phillips, R., Rossiter, D. \& Winn, J. (2000). Developing a framework for a usable and useful inventory of computer-facilitated learning and support materials in Australian universities. Evaluations and Investigations Report 99/11, Department of Employment, Education, Training and Youth Affairs, Canberra. [viewed 1 Nov 2003, verified 31 Oct 2005] http:/ / www.dest.gov.au/archive/highered/eippubs/ eip99-11/split.htm

Murphy, G. (1987). The impact of new communication technologies on role and function in traditional educational support services. Australian Journal of Eductional Technology, 3(1), 25-32.

http:/ / www.ascilite.org.au/ajet/ajet3/murphy.html

Neff, R. K. (1985). Merging libraries and computer centres: Manifest destiny or manifestly deranged? An academic services perspective. EDUCOM Bulletin, Winter, 8-10.

Oates, R. H. (2001). What works for teachers: New approaches to technology professional development. Electronic School.com. [viewed 31 Oct 2005] http: / / www.electronic-school.com/2002/01/0102f2.html

Ottmann, T. \& Tomek, I. (Eds) (1998). Proceedings of ED-MEDIA/ED-TELECOM 98, World Conference in Educational Multimedia and Hypermedia and World Conference on Educational Telecommunications, Freiburg.

Poole, B. J. (1997). Education for an Information Age: Teaching in the Computerized Classroom, Second edition. McGraw Hill, New York.

Pressman, R. S. (1997). A Developer's Handbook to Interactive Multimedia: A Practical Guide for Educational Applications. Kogan Page, London.

Prpic, J. K. \& Kanjananapanyakom, R. (2004). The impact of cultural values and norms on higher education in Thailand. Proceedings HERDSA Conference 2004. http: / / herdsa2004.curtin.edu.my/Contributions / NRPapers/P064-jt.pdf [viewed 31 Oct 2005]

Relan, A. \& Gillani, B. (1997). Web-based instruction and the traditional classroom: Similarities and differences. In B.H. Kahn (Ed), Web-based Instruction. Educational Technology Publications, Englewood Cliffs NJ.

Rossiter, D. (1997). Future uses of digital technologies in teaching and learning in higher education: An evaluation. In What works and why. Proceedings ASCILITE Conference 1997. Perth.

http: / / www.ascilite.org.au/ conferences/ perth97/ papers/Rossiter/Rossiter.html 
Suanpang, P., Petocz, P. \& Reid, A. (2004). Relationship between learning outcomes and online access. Australasian Journal of Educational Technology, 20(3) 371-387. http: / / www.ascilite.org.au/ajet/ ajet20/suanpang.html

Shotsberger, P. (1997). Emerging roles for instructors and learners in the web-based instruction classroom. In B.H. Kahn (Ed), Web-based Instruction. Educational Technology Publications, Englewood Cliffs NJ.

Venables, J. (1998). Graduate education on the Internet. Physics Education, 33(3), 157163.

Waterworth, P.G. \& Tesaputa, K (1999). Issues in using computer technologies in school administration' Paper presented at the Fifth UNESCO-ACEID International Conference, Bangkok, December.

Waterworth, P.G., Segrave, S. \& Warren, C. (2001). New pedagogies: using constructivist insights in developing online studies in education. In Lertchalolarn, C. et al (Eds), Reforming Teacher Education for the New Millennium: Searching for New Dimensions. Proceedings of the International Conference, Chulalongkorn University in association with SEAMEO RIHED, Bangkok, July 2000.

Whattananarong, K. (2004). An experiment in the use of mobile phones for testing at King Mongkut's Institute of Technology, North Bangkok, Thailand. Paper presented at the International Conference on Making Education Reform Happen: Learning from the Asian Experience and Comparative Perspectives. Bangkok. [viewed 31 Oct 2005]

http: / / www.seameo.org/vl/krismant/mobile04.pdf

Yetton, P. et al (1997). Managing the introduction of technology in the delivery and administraton of higher education. Evaluations and Investigations Report, Department of Employment, Education, Training and Youth Affairs, Canberra. [viewed 1 Nov 2003, verified 31 Oct 2005]

http: / / www.dest.gov.au/archive/highered/eippubs/eip9703/front.htm

Dr Prachit Intaganok is the Dean, Faculty of Education at Surindra Rajabhat University [http: / / www.srru.ac.th/], 186 Sirin-Prasat Road, Muang Surin, 32000, Thailand. Email: g37pit@hotmail.com

Dr Peter Waterworth is an associate of the Faculty of Education, Deakin University [http:/ / www.deakin.edu.au/] in Australia and works as a visiting lecturer and research scholar at the Surindra Rajabhat Univerity. Address: 25 Rowitta Drive, Glen Waverley Vic 3150, Australia. Email: petexx@deakin.edu.au

Ms Siwaporn Srisamai is a lecturer in the Communication Arts Program in the Faculty of Management Sciences. She is currently on secondment to work for the Peace Corp in Thailand and the US. Address: Department of Communication Arts, Surindra Rajabhat University, 186 Sirin-Prasat Road, Muang Surin, 32000, Thailand. Email: to_siwaporn@hotmail.com 